\title{
Article
}

\section{The I in My Text: Revisiting Critical Feminist Identity Politics, Refusing the Allures of Purity}

\author{
Laura Levitt
}

\begin{abstract}
In this essay, I return to the moves to the first person I made in Jews and Feminism: The Ambivalent Search for Home (Routledge, 1997) in order to consider what this approach has to offer us in the present. By insisting on the kinds of complexity that informed this feminist, decidedly impure enactment of critical identification, I make clear that identity is not about purity. Instead, I call attention to the hybrid, messy, and even contradictory lived realities so many of us inhabit. By returning to my own early engagement with placing myself in my writing as a scholar of Jewish studies, I consider the implications of reanimating these practices in the present. In other words, by interrogating what it meant in the 1990s to claim a Jewish feminist position, I consider anew how we position ourselves in our work in the present. Along the way, I challenge alt-right claims to "identity politics" as well as certain forms of liberal pluralism. By revisiting what it meant to write in the first person and to embody this feminist critical scholarly legacy, I hope to revive a strand of that feminist genealogy to imagine a more capacious future for embodied Jewish feminist scholarship.

Keywords: feminist, identity politics, intersectionality, American Jewish, purity, liberal pluralism
\end{abstract}


This essay lays claim to an identity politics of multiple and shifting identifications grounded in critical feminist theory, including my own work. I use both this theory and my enactment of it to challenge Richard Spencer's alt-right claims to white nationalism and white racial purity as an acceptable form of liberal-pluralistic identity politics.

Returning to the legacy of radical feminist critical identity politics from the 1980s and 1990s_-work that combined poststructural theory with powerful first-person writing-I revisit my own earliest Jewish feminist work to resist, in the name of "identity politics," the very discourse that Spencer attempts to reclaim, including radical forms of contemporary Zionism that advocate for a Jewish-only Israeli State. ${ }^{1}$ I conclude by explaining the confluences between this feminist position and contemporary intersectional feminist theorizing.

\section{JEWISH FEMINIST CRITICAL IDENTITY POLITICS REVISITED}

What does it mean for us to inhabit the work we do as scholars in Jewish studies and write in the first person? How does a move to the first person help us resist the kinds of reifications that haunt our contemporary moment and its disturbing invocations of a new form of identity politics, a politics of purity that refuses the complexity and contradictions at the heart of ongoing feminist scholarship?

On the map of my many homes, in this book, I try to locate my physical homes in Atlanta and Philadelphia, my liberal Jewish home in America, and my academic homes within and between the disciplines of Jewish studies, feminist studies, and religion. ... These homes have allowed me to venture forth into an interrogation of the promises of my various Jewish, liberal and feminist traditions. Although throughout much of this book I am critical of these legacies, I do not abandon them, for I do not believe that that is possible. Like 317 Ninth Street, where I no longer physically live, other homes, past and present—my parent's home, rabbinic, liberal Jewish, and liberal Jewish feminist Judaisms - remain part of the landscape I call home, as do my homes in Philadelphia, the ideology of liberalism, and feminist studies. 
What's identity got to do with home? In order to answer this question for myself, I want to bring the pieces of my story together now in a slightly different way. ... Although I have made clear that my rape was not the only motivation for this book, it has been constitutive. It, perhaps more than anything else, has called into question so many of my beliefs about what constitutes home. These include my construction of my heterosexuality, my notions of family, of domesticity, of agency, and of personal safety and protection. To say I am a Jewish feminist in light of all that has happened to me, in light of all that I have done to make some sense of all of these disparate experiences is what this book is about. I have posed to myself the challenge to be honest about the complexity and contradictions of my experiences. The fact that the resources of my various traditions were not able to do this for me in any simple way has led me to this more partial, less absolute account of my identity as a kind of home. ${ }^{2}$

This is, in part, how I positioned myself as a feminist scholar of Judaism in the first chapter of my first book. My professional life began in the first person: I presented the multiplicity of my position, the promises and limitations of the many discourses that shaped me, and the trauma that shattered any semblance I ever had of any singular or coherent self. There was already never just one place or tradition I could call home.

I came to understand my position through my engagement with feminist theory, and more specifically, the now classic collection, Feminist Studies/Critical Studies. This work contains Chandra Mohanty and Biddy Martin's powerful essay on feminist politics and home that inspired my work and my efforts to think about my identities as homes. The collection's editor, Teresa de Lauretis, was the first scholar to show me the deep connections between a post-structurally inflected critical theory and feminist identity politics. She and her contributors brought together these discourses in productive ways, ${ }^{3}$ and her introduction set the stage for some of those crucial multivalent interventions.

In "Feminist Politics: What's Home Got to Do with It?" Mohanty and Martin show what feminist identity politics has to offer critical, 
poststructural theory through a close reading of Minnie Bruce Pratt's "Identity Skin Blood Heart." Pratt's essay, her contribution to the volume Yours in Struggle: Three Feminist Perspectives on Anti-Semitism and Racism (1984), ${ }^{4}$ written with Elly Bulkin and Barbara Smith, is a classic example of feminist identity politics and its efforts to work across differences, confronting racism and antisemitism. Focusing on Pratt's essay, Mohanty and Martin lay claim to the confluence of seemingly contradictory positions. They challenged what were then essentialist assumptions about feminist alliance politics, focusing on works like Pratt's to argue for the contingency and complexities of critical feminist work. As de Lauretis explains in her introduction: "As we look back on the history of feminism over the past two decades, then, we can trace the permanence of certain critical terms, such as the emphasis on subjectivity and the centrality of gender to any account of social processes, but can also see the developments or shifts in them, as well as other, equally fundamental concepts. Identity and consciousness are being redefined substantially." ${ }^{5}$ This rethinking of consciousness and identity are precisely what Mohanty and Martin show Pratt doing in her essay. They argue that instead of reifying her identity, Pratt interrogates her complicated position. This is what I in turn tried to do in Jews and Feminism.

As de Lauretis explains, this is a "gendered, heterogeneous, and heteronomous subject," who is produced in and through the horizons of meaning available in the culture at any given time. These decidedly messy, contradictory positions are what distinguish feminist practice, and de Lauretis as well as Mohanty and Martin insist that critical theory grapple with this complex feminist subject presented in works like Yours in Struggle. As de Lauretis explains, critical theorists need to claim feminism "because of the epistemological priority which feminism has located in the personal, the subjective, the body, the symptomatic, the quotidian as the very material inscription of the ideological." She called this "the ground where socio-political determinations take hold and are real-ized." This is where many of us who lay claim to this legacy of feminist critical identity politics began, and this kind of identification was never about reification. 
More pointedly, as de Lauretis wrote:

What is emerging in feminist writing is ... the concept of a multiple, shifting, and often self-contradictory identity, a subject that is not divided in, but rather at odds with, language; an identity made up of heterogeneous and heteronomous representations of gender, race, and class, and often indeed across languages and cultures; an identity that one decides to reclaim from a history of multiple assimilations, and that one insist on as a strategy: "I think," writes Elly Bulkin, "of all the women [of mixed heritage] who, told to choose between or among identities, insist on selecting all."»

These were feminist scholars, writers, and activists, many of whom would later foster all kinds of queer theorizing and politics, doing something called "identity politics." Identity politics boldly proclaimed the complicated specificity of multiple, shifting, and even contradictory positions. It was in this spirit that I wrote about my own desire: “To say I am a Jewish feminist in light of all that has happened to me, in light of all that I have done to make some sense of all of these disparate experiences."

\section{IT'S NOT ABOUT PURITY}

Because recent deployments of identity politics are so radically at odds with this messy vision, I turn to Latinx feminist theorist María Lugones, who wrote eloquently about the problems posed by discourses of purity. Lugones opens her haunting, lyrical, and timely 1994 Signs essay "Purity, Impurity, and Separation" with a question: Is separation (of identities) "always or necessarily an exercise in purity"? ${ }^{10}$ She does this by describing the delicate task of separating a yolk from an egg white. She explains that she usually intends to do that procedure "cleanly," but then goes on to discuss how failure is often inevitable, requiring her to continue to make adjustments. In this way, she argues, the task gets done even if "a bit messily." 11 
Lugones uses this quotidian kitchen procedure as her way into a discussion of "the politics of purity and how they bear on the politics of separation," 12 arguing for what she calls mestizaje, a Latinx-informed stance of impurity and resistance that is both deeply contradictory and ironic. Lugones insists that there are aspects of our identities that cannot be cleanly separated from each other. Even when we parse out some of these, the traces of those others are still there.

In sharp contrast to this messy vision, Lugones explains that the world of purity is made up of "a cluster of concepts" that include "control, purity, unity, categorizing." 13 Together they form a network where the logic of purity rules. It demands that there always be unity underlying multiplicity both within the individual and in the constitution of collectives. In all of these instances, the demand for singularity, control, and unity effaces the lively, messy lived experiences that characterize everyday life.

This hybridity is what feminist critical theories of identity politics was all about. Many of us embraced our complex subject positions in the 1980s and 1990s to resist the idea of a single female or feminist position. These enactments were never about fragmentation-itself a marker of the discourse of purity that demanded wholeness and unity-but about complexity and contractions. My own efforts were an attempt to honestly appraise my own complex and contradictory position, my disappointment and love for the various traditions that had defined me.

At this later moment in this the time of Trump, to engage this work is all about undoing precisely these all-too-prevalent instantiations of the logic of purity that Lugones rejects. ${ }^{14}$ At its best, this is what the 2017 Women's March was all about. It tried to offer a living example of this complexity, bringing together a broad range of people even as it pushed against the assumption that there is some pure instantiation of "woman." Let me say this a bit differently. We live in a time when it is almost impossible to see forms of identification in their hybrid, impure, messy lived realities. We work with broken eggs in a landscape increasingly informed by an insistence on clearly demarcated boundaries and borders, where hybridity and contradiction are suspect. 


\section{RICHARD SPENCER'S WHITE NATIONALIST IDENTITY POLITICS: THE LIMITS OF LIBERAL PLURALISM}

Just after the 2016 election, I listened to a long radio interview with Richard Spencer on All Things Considered. This was the first time I heard, at length and in depth, the contours of alt-right, white-nationalist identity politics. It would not be the last. In this interview, Spencer laid out his pluralist vision. Taking to heart the notion that all people deserve a place at the table (his version of liberal pluralism), in modulated prose, Spencer described how white Americans have been left out of the feast and that what he and his compatriots wanted was what lots of minority groups presumably already have-a place of their own, an identity of their own. In elaborating his position, Spencer likened his quest to what Jewish nationalists and other nationalists want: a home, a cultural position of their own. He wants every group to have their own thing, be it a community or nation-state with defined borders.

About European Americans, Spencer say he has a special relationship. "I care about us more," he explained. "That's all I'm saying. But I respect identitarians of other races. And I actually can see eye to eye with them in a way that your average conservative can't." He went on in this interview to say that segregation is natural, as it happens "at lunchtime, at PE," or even "in terms of afterschool play." 15 This is the kind of separation Lugones warned against, and it is what Mohanty and Martin show Pratt working to undo in her contribution to Yours in Struggle. By claiming the specificity of her own white, southern, Christian position, they argue, Pratt was not trying to move away from her African American and Jewish colleagues. Rather, she was attempting to come closer by revealing and breaking down the institutions and histories that had separated her from other women.

Part of what I found so jarring about Spencer's account, the contours of which become that much more vivid as he will go on to claim a "White Zionist" position (Kestenbaum), is that already in this first instantiation, Spencer uses liberal pluralism and identity politics, tactics once honed by the Left, including feminists, to articulate his own political position. ${ }^{16}$ And yet, his stance, unlike earlier Left movements that deployed these tactics, such as the Civil Rights Movement, does not address either historical or 
structural inequities and their ongoing effect on American public life, much less the goals of those Left efforts to challenge forms of injustice. Instead, Spencer deftly uses these tactics to efface these structural problems and social hierarchies. He takes them as givens so as not to disrupt the asymmetries of power already in place. He then presumes the playing field already level. Instead of privileging those who have been historically oppressed, he makes white people-white European Americans-into their own minority group. And in the name of equality, he suggests that unlike these other groups, white European people have been oppressed. They are also trying to take their place at this clearly partitioned table.

In her powerful and early critique of liberal pluralism, queer theorist and religion scholar Janet Jakobsen suggests that without accounting for historical asymmetries of power, legacies of oppression and exploitation, liberal pluralism is open to this kind move. As she explains, "The horizontal placement of various 'differences' fails to articulate either power relations or historical conflict among 'different' groups." ${ }^{17}$ She goes on to argue that such deployments produce a version of diversity that is made up of multiple "units" of difference. And then she explains, "these coherent 'units' of difference are placed in horizontal lists, producing clear boundaries." 18 In this arrangement then, all differences are made into "benign variation (diversity) . . rather than as ... conflict or struggle, or the threat of disruption." ${ }^{19}$ This is the brilliance and the insidiousness of Spencer's position. The white European difference he proclaims is simply a "benign variation"; there is no sense of the histories of colonization, appropriation, or enslavement in this now seemingly level playing field. And to be clear, for this strategy to work, all differences must become singular and unified, follow closely to the logic of purity, separable and distinct.

\section{WHITE ZIONISM}

An August 2017 article in the Forward begins: "In an interview on Israeli TV, Richard Spencer said that Israelis should ignore the anti-Semitism of the 'alt-right' and instead respect and empathize with his desire 
to create a whites-only ethno state." ${ }^{20}$ Here, Spencer makes vivid his pro-Zionist position: a Jewish state for the Jews, a white ethno-state for white Europeans. In fact, for Spencer this form of radical Zionism with its logic of clear boundaries and rigid identities not only coexists with a vision of whites-only identity politics, but it also is an inspiration. Antisemitism can be ignored in the name of ethno-nationalism, including a very narrow and disturbing form of Jewish nationalism as exclusively Jewish. Needless to say, this account of an ethnonationalist Jewish position is the rigid inverse of the multiple, shifting, and contradictory Jewish feminist position I presented earlier. And in a different way, this more exclusivist and nationalist form of religion is also echoed in the position of white evangelical Protestants. As religion scholar Kathleen Sands explains: "The religion that founds their ideal social order no longer is seen as an essence available in all true religions. On the contrary, evangelical Protestantism alone is thought to be the true and only religious foundation for the American polity. It is as if generic religion, having been stripped of this feigned universality, is being morphed by evangelicals into an unabashedly ethnocentric nationalism."21 This kind of ethnocentric public politics of exclusion is precisely what Spencer wants to advance. It is also at the core of his admiration for an ethnocentric Jewish nationalism, a position recently codified into Israel's new law declaring the country the "Nation-State of the Jewish People." In this instance, Spencer conflates ethnicity and religion for Jews in Israel, and this in turn allows him to conflate white nationalism and a form of evangelical Protestantism.

\section{JEWS AND FEMINISM, IMPERMANENCE, AND INTERSECTIONS}

In the introduction to Jews and Feminism: The Ambivalent Search for Home, I wrote, "This book began as and remains an interrogation of what it means to claim and configure a Jewish feminist identity in the midst of conflicting visions and material conditions. It makes explicit how and in what ways it is crucial to theorize out of the contingent places we call 
home." 22 I went on to explain that the book "also demonstrates how theory can help explain in nuanced and powerful ways the complexities of our lives. It shows how theory can enable us to explore the seams in the construction of our identities within the constraints of various social, cultural, and political configurations of power and desire." ${ }^{23}$ This is how I set up my enactment of the kinds of theoretical and political interventions that Lugones, de Lauretis, and Mohanty and Martin advocate and see in a work like Pratt's.

It is chilling to consider how far away from this vision we are given the rise of Jewish ethnonationalism. When I first took this stance, I was positioning myself in alliance with a full range of feminist activists, scholars, and writers who insisted on claiming their multiple and contradictory identities as they engaged powerfully with each other in their differences. But this also demands resisting various normative claims to a singular Jewish position whether religious, ethnic, or nationalist.

I never wanted a place at an already-set table. Instead, the idea was to break bread (and lots of eggs) with the African American writers and activists of the Combahee River Collective, the women of color who contributed to This Bridge Called My Back; Minnie Bruce Pratt, Barbara Smith, and Elly Bulkin who together wrote Yours in Struggle; and Adrienne Rich, Audre Lorde, and Irena Klepfisz and Melanie Kaye/Kantrowitz who edited Tribe of Dina. ${ }^{24}$ I still want to stand with all of these women. Their work inspired the theoretical interventions made by de Lauretis, Mohanty, and Martin in Feminist Studies/Critical Studies, and my own. They inspired me to write in the first person, and I have done so ever since. Their work continues to inform my scholarship and my writing. The complex historical richness of their work, their attention to legacies of oppression and power, are precisely the central concerns of an ongoing critical feminist identity politics. And it is these very commitments that are effaced by Richard Spencer's position. Instead of refusing to choose and embracing the messy hybridity and contradictions of our positions, what Lugones sees as their impurity, Spencer demands an ever more stringent set of bounded positions and this includes his white Zionism. He demands purity. This is, in the end, the very opposite of the legacy 
of critical feminist identity politics. I am aware of the didacticism of this stark contrast, but the urgency of these times demands this kind of clarity.

Lugones argues that purity is not a life-affirming option. Rather, as she explains, it is an ahistorical logic that hides the very labor of its own construction. ${ }^{25}$ What is needed, she insists, is attention to those often invisible labors. They are the sites where we come together, where, in our differences, we make food and perhaps more life-giving politics based on messy, partial, imperfect affiliations. This is an identity politics that refuses to be pinned down, to be defined definitively. It is a living entity. As I wrote so long ago, "although nothing is permanent, traces of the past remain with us as part of a shifting vision." ${ }^{26}$ In claiming all of these partial commitments and affiliations, we come together with others, people not like us, and figure out how to work together.

Long before there was what is now referred to as "intersectional feminist theory," ${ }^{27}$ there were many feminists thinking critically about identification in these epistemically challenging terms. Although contemporary intersectional feminist politics emerges out of the kinds of critical feminist identity politics I have been describing, there are some important distinctions that I want to make. But I also want to be clear that these practices and commitments are profoundly linked, and in many instances, they may be (and frequently already are) used synonymously. In this context, however, I want to resist that language. I do this for a number of reasons. Let me conclude with a few explanations.

First and foremost, although profoundly powerful, Kimberlé Crenshaw's initial work was an intervention into the realm of the law. She was trying to bring the kinds of insights I have been discussing into legal discourse where rigid categories are often crucial. Legal discourse demands its own kind of purity, clear categories, and careful separations based on legal precedent. The brilliance of Crenshaw's "intersections" and "vectors" are that they have offered a way of making legible the very complexities and contradictions at the heart of a feminist critical identity politics in a legal setting. This work has helped transform the law. Crenshaw has made it possible for black women to be recognized as both black and female in legal proceedings. And this is an extremely important innovation. 
But, the price of that intervention as it moves outside of the realm of law and becomes a more generalized way of addressing differences has been, I believe, less helpful. It has produced a more static and more exacting set of differentiations among and between differences that are often experienced simultaneously. Intersectionality seems to call for precision, a single point where all of our differences meet. I do not believe we experience difference within, among, or between ourselves and others in this fashion. Our differences, and the ways in which they interact, ebb and flow. And I do not want to lose this more dynamic vision.

And finally, in a different way, I also want to resist positioning myself as an intersectional being that has to be a subject before the law. This is especially important to me in the kinds of theorizing and writing that I do. And, to be clear, I quite intentionally do this work outside of the realm of jurisprudence. As a survivor of rape, I have great ambivalence about the law because the law, like for the vast majority of people who are raped, has not protected me. Nor has it offered many of us even the semblance of justice. As such I am extremely reluctant about allowing its categories and its demands to shape how I think about my position or those of so many others for whom the law, even at its intersectional best, struggles to even begin to appreciate. And, most pointedly in this context, I want to reaffirm feminist identity politics in the face of ethnonationalist efforts to radically redefine this legacy in the present. For me, this complex and layered feminist theory continues to be a powerful tool to fight ethnonationalism.

\section{NOTES}

1. This is the kind of position institutionalized in the new Israeli law passed during the summer of 2018. For the text of the law, see Wootliff, "Final Text," and for more information, see Halbfinger and Kershner, "Israeli Law."

2. Levitt, Jews and Feminism, 15-16.

3. For more on this text and some of its shortfalls, see Levitt, Jews and Feminism, especially chapters 7 and 8 .

4. Pratt, "Identity Skin Blood Heart."

5. De Lauretis, "Feminist Studies," 10. 
6. De Lauretis, "Feminist Studies," 11.

7. De Lauretis, "Feminist Studies," 11-12.

8. De Lauretis, "Feminist Studies," 9.

9. Levitt, Jews and Feminism, 15-16.

10. Lugones, "Purity, Impurity, and Separation," 458.

11. Lugones, "Purity, Impurity, and Separation," 458.

12. Lugones, "Purity, Impurity, and Separation," 458.

13. Lugones, "Purity, Impurity, and Separation," 463.

14. For a fascinating and different take on feminist appeals to purity, it is interesting to consider the ways that first-wave American feminists, especially Protestant women, used the discourse of purity to build many of their campaigns. See Sands, 315: "It is well-recognized that the abolition movement, the temperance movement, the women's peace movement, and various purity movements were substantially inspired and often supported by religion and for the women involved in those movements religion became a bridge to public life."

15. Spencer, "We're Not Going Away," interview with Kelley McEvers.

16. This is not a new tactic. It was also used in the 1980s and 1990s. See for example, Cindy Patton, “Tremble, Hetero Swine!" and "Refiguring Social Space." I thank Byron Lee for these important references.

17. See Jakobsen, Working Alliances, 9. For a different deployment of this critique in relation to the work of photographer Frederic Brenner, see Levitt, "Photographing American Jews," especially 78-80.

18. Jakobsen, Working Alliances, 9.

19. Jakobsen, Working Alliances, 9-10.

20. Kestenbaum, "Richard Spencer."

21. Sands, "Feminisms and Secularisms," 324.

22. Levitt, Jews and Feminism, 3.

23. Levitt, Jews and Feminism, 3.

24. See, for example, works by the Combahee River Collective, Cherrie Moraga and Gloria Anzaldua, Adrienne Rich, Audre Lorde, Melanie Kaye/ Kantrowitz and Irena Klepfisz, and Evelyn Beck. For a recent example of the abiding power of critical feminist identity politics, see the November 15, 2017, Combahee River Collective "Mixtape." 
25. Lugones, "Purity, Impurity, Separation,” 365.

26. Levitt, Jews and Feminism, 164.

27. See Crenshaw, "Mapping the Margins" and "Demarginalizing."

\section{BIBLIOGRAPHY}

Beck, Evelyn Beck, ed. Nice Jewish Girls: A Lesbian Anthology. Boston: Beacon Press, 1989.

Combahee River Collective. “A Black Feminist Statement.” In Theorizing Feminism:

Parallel Trends in the Humanities and the Social Sciences, 2nd ed., edited by Anne

C. Herrmann and Abigail J. Stewart, 29-37. Boulder: Westview Press, 2001. “Mixtape: Black Feminist Sonic Dissent Then and Now.” Sponsored by the Barnard Center for Research on Women. New York: Barnard College, November 15, 2017. Accessed November 6, 2017. https://www.eventbrite .com/e/combahee-river-collective-mixtape-black-feminist-sonic-dissent-then -and-now-tickets-36867536795.

Crenshaw, Kimberlé Williams. "Demarginalizing the Intersection of Race and Sex: A Black Feminist Critique of Antidiscrimination Doctrine, Feminist Theory, and Antiracist Politics." University of Chicago Legal Forum 14, no. 5 (1989): 38-54.

. "Mapping the Margins: Intersectionality, Identity Politics and Violence Against Women.” Stanford Law Review 43, no. 6 (July 1991): 1241-99.

de Lauretis, Teresa. "Feminist Studies/Critical Studies: Issues, Terms, and Contexts." In Feminist Studies/Critical Studies, edited by Teresa de Lauretis, 1-19. Bloomington, IN: Indiana University Press, 1986.

Halbfinger, David M., and Isabel Kershner. "Israeli Law Declares the Country the 'Nation-State of the Jewish People."' New York Times, 19 July 2018. https:// www.nytimes.com/2018/07/19/world/middleeast/israel-law-jews-arabic.html. Jakobsen, Janet. Working Alliances and the Politics of Difference. Bloomington, IN: Indiana University Press, 1997.

Kaye/Kantrowitz, Melanie, and Irena Klepfisz, eds. Tribe of Dina: A Jewish Women's Anthology. Boston: Beacon Press, 1989.

Kestenbaum, Sam. 'Richard Spencer Touts Himself as 'White Zionist' in Israeli Interview." Forward, 17 August 2017. Accessed 14 October 2017. http:// 
forward.com/fast-forward/380235/richard-spencer-touts-himself-as-white -zionist-in-israeli-interview/.

Levitt, Laura. Jews and Feminism: The Ambivalent Search for Home. New York: Routledge, 1997.

___ . "Photographing American Jews: Identifying American Jewish Life." In Mapping, Jewish Identities, edited by Laurence Silberstein, 65-96. New York: New York University Press, 2000.

Lorde, Audre. Sister Outsider. Trumansburg, NY: Crossing Press, 1984.

Lugones, Maria. “Purity, Impurity, and Separation.” Signs 19, no. 2 (1994): 458-79. Mohanty, Chandra, and Biddy Martin. "Feminist Politics: What's Home Got to

Do with It?" In Feminist Studies/Critical Studies, edited by Teresa de Lauretis, 191-212. Bloomington, IN: Indiana University Press, 1986

Moraga, Cherrie, and Gloria Anzaldua, eds. This Bridge Called My Back, Fourth Edition: Writings by Radical Women of Color, 4th ed. Albany, NY: State University of New York Press, 2015.

Patton, Cindy. "Refiguring Social Space." In Social Postmodernism: Beyond Identity Politics, edited by Steven Seidman and Linda Nicholson, 216-49. New York: Cambridge University Press, 1995.

___ _. "Tremble, Hetero Swine!” In Fear of a Queer Planet, edited by Michael Warner, 143-77. Minneapolis: University of Minnesota Press, 1993.

Pratt, Minnie Bruce. “Identity Skin Blood Heart.” In Yours in Struggle: Three Feminist Perspectives on Anti-Semitism and Racism, edited by Elly Bulkin, Minnie Bruce Pratt, and Barbara Smith, 11-63. Brooklyn, NY: Long Haul Press, 1984.

Rich, Adrienne. Blood, Bread, and Poetry: Selected Prose 1979-1985. New York: W. W. Norton Press, 1986.

Sands, Kathleen. "Feminisms and Secularisms." In Secularisms, edited by Janet Jakobsen and Ann Pellegrini, 308-29. Durham: Duke University Press, 2008. Spencer, Richard. “We're Not Going Away’: Alt-Right Leader in Trump Administration.” Interview with Kelly McEvers, 17 November 2016. All Things Considered. Accessed 5 October 2017. http://www.npr.org/2016/11 /17/502476139/were-not-going-away-alt-right-leader-on-voice-in-trump -administration. 
Woofliff, Raoul. "Final Text of Jewish Nation-State Law, Approved by the Knesset Early on July 19." The Times of Israel, 19 July 2018. https://www.timesofisrael .com/final-text-of-jewish-nation-state-bill-set-to-become-law.

\section{CONTRIBUTOR}

Laura Levitt is a professor of religion, Jewish studies, and gender at Temple University, where she works on Holocaust memory, gender, contemporary American Jewish life, and visual and material culture. She is just completing a book about trauma and loss and how material artifacts make these painful legacies manifest, The Afterlives of Objects: Holocaust Evidence and Criminal Archives (Penn State University Press, forthcoming). She is the author of American Jewish Loss after the Holocaust (New York University Press, 2007) and Jews and Feminism: The Ambivalent Search for Home (Routledge, 1997). Levitt is an editor of Impossible Images: Contemporary Art After the Holocaust (New York University Press, 2003) and Judaism Since Gender (Routledge, 1997). With Tracy Fessenden (Arizona State University) and David Harrington Watt (Haverford College), she edits the North American Religions series at NYU Press. 